\title{
ASSESSING IN VITRO SOLUBILIZATION POTENTIAL OF DIFFERENT ZINC SOLUBILIZING BACTERIAL (ZSB) ISOLATES
}

\author{
Venkatakrishnan Sivaraj Saravanan ${ }^{1 *}$; Sudalayandy Rama Subramoniam ${ }^{2}$ and Savariappan Anthoni Raj ${ }^{3}$ \\ ${ }^{1}$ Centre of Advanced Studies in Agricultural Microbiology Tamil Nadu Agricultural University, Coimbatore, India; ${ }^{2}$ Centre For \\ Soil And Crop Management Studies, TNAU, Coimbatore, India; ${ }^{3}$ Dean, Agricultural College \& Research Institute, Trichy, India.
}

Submitted: March 12, 2003; Returned to authors: July 24, 2003; Approved: February 10, 2004.

\begin{abstract}
Zinc solubilizing ability of Bacillus sp. and Pseudomonas sp. was assessed using zinc oxide, zinc sulphide (sphalerite) and zinc carbonate in both plate and broth assays. ZSB-O-1 (Bacillus sp.) showed highest dissolution in the zinc sulphide (Sphalerite ore), with $2.80 \mathrm{~cm}$ of dissolution zone and $14.50 \mathrm{~cm}^{2}$ of area in the plate assay and $13.60 \mathrm{mg} \mathrm{kg}^{-1}$ of zinc in the broth assay on the $15^{\text {th }}$ day after inoculation. The ZSB-S-2 (Pseudomonas sp.) showed more solubilizing ability in the zinc oxide, with $3.30 \mathrm{~cm}$ clearing zone and $20.43 \mathrm{~cm}^{2}$ area in the plate assay and $16.40 \mathrm{mg} \mathrm{kg}^{-1}$ of zinc in the broth assay over the same inoculation period. The isolate ZSB-S-4 (Pseudomonas sp.) has highest solubilizing potential in zinc carbonate with $6.20 \mathrm{~cm}$ of dissolution zone and $13.40 \mathrm{~cm}^{2}$ area in the plate assay and $13.40 \mathrm{mg} \mathrm{kg}^{-1}$ of zinc in the broth assay. Thus, the solubilization potential varies among different cultures. The solubilization might be due to production of acids by the culture, since the $\mathrm{pH}$ of the culture broth has been shifted form 7.0-7.3 to 4.8-6.5 after 15 days of inoculation. The zinc tolerance limit for two cultures (ZSB-O-1 and ZSB-S-2) was studied and determined to be upto $100 \mathrm{mg} \mathrm{kg}^{-1}$ of zinc in the in vitro broth assay.
\end{abstract}

Key words: Bacillus sp., Pseudomonas sp., zinc solubilizing bacteria

\section{INTRODUCTION}

Microorganisms require various nutrients for their growth and metabolism. Among the nutrients, zinc is an element present in the enzyme system as co factor and metal activator of many enzymes (9). The role of zinc in the nutrition and physiology of both eukaryotic and prokaryotic organisms is widely studied, especially its importance for activity of many enzymes (7). Zinc deficiency in fungi and bacteria is accompanied by impairment of the formation of pigments such as melanin, chrisogenin, prodigiosin, subtilin and others (4). A few fungal genera possess immense potential of solubilizing zinc tolerating a high zinc level Aspergillus niger was found to grow under $1000 \mathrm{mg} \mathrm{Zn}$ and this fungi is used to quantify zinc in soils containing low zinc (2 $\mathrm{mg} \mathrm{kg}{ }^{-1}$ available zinc) (2). Lichens and conifers are conspicuous for their high zinc content and the highest concentration of this element has been found in poisonous mushrooms (12). Zinc solubilizing potential of few bacterial genera has been studied. Hutchins et al. (8), reported that Thiobacillus thioxidans, $T$. ferroxidans and facultative thermophilic iron oxidizers solubilized zinc from sulphide ore (sphalerite). Exogenous application of soluble zinc sources, similar to fertilizer application, has been advocated to various crops. This causes transformation of about 96-99 per cent of applied available zinc to various unavailable forms. The zinc thus made unavailable can be reverted back to available form by inoculating a bacterial strain capable of solubilizing it. Since zinc is a limiting factor in crop production, this study on zinc solubilization by bacteria has an immense importance in zinc nutrition to plants.

\section{MATERIALS AND METHODS}

Seventeen bacterial isolates were obtained based on the solubilizing zone formation on the modified Bunt and Rovira

*Corresponding author. Mailing address: Centre of Advanced Studies in Agricultural Microbiology, Tamil Nadu Agricultural University, Coimbatore641 003. Tamil Nadu, India. E-mail: saraphd2003@yahoo.com 
media containing $0.1 \%$ insoluble $\mathrm{ZnO}$ (3). Bacillus sp. (ZSB-O1) isolated from zinc ore sphalerite and Pseudomonas sp. (ZSBS-2 and ZSB-S-4) isolated from paddy soil were screened as efficient zinc solubilizing isolates (ZSB) and tested on different insoluble zinc compounds. The solubilization potential was assessed both qualitatively and quantitatively under in vitro conditions.

\section{Plate assay}

The isolates were inoculated into agar medium containing $0.1 \%$ insoluble zinc compounds viz, $\mathrm{ZnO}, \mathrm{ZnS}$ and $\mathrm{ZnCO}_{3}$. The test organisms (ZSB-O-1, ZSB-S-2 and ZSB-S-4) were inoculated on these media and incubated at $30^{\circ} \mathrm{C}$ for 48 hours. The diameters of the clearing zones around the colonies were measured.

\section{Broth assay}

The bacterial isolates were inoculated separately to basal medium supplemented with $0.1 \%$ insoluble zinc compounds. The solubilization of zinc from laboratory grade $\mathrm{ZnO}, \mathrm{ZnCO}_{3}$ and $\mathrm{ZnS}$ (Sphalerite ore material) by ZSB was assessed. Basal medium (glucose-10.0 g; ammonium sulphate- $1.0 \mathrm{~g}$; potassium chloride-0.2 g; dipotassium hydrogen phosphate-0.1 g; magnesium sulphate- $0.2 \mathrm{~g}$; distilled water $-1000 \mathrm{ml}$, $\mathrm{pH} 7.0$ ) was prepared, splitted in $50 \mathrm{ml}$ aliquots in $100 \mathrm{ml}$ Erlenmeyer flasks and $0.1 \%$ of these chemicals were added, steam sterilized for 30 minutes in an autoclave for 3 consecutive days. Then the flasks were inoculated with $1 \mathrm{ml}$ suspension of the test culture with a cell load of $10^{7}$ cells $\mathrm{ml}^{-1}$. Three flasks were maintained with an uninoculated control for each treatment. Experiments were done in triplicate. The samples were withdrawn at $0,7,14$ and 20 days intervals, centrifuged to remove the debris and cells. Ten $\mathrm{ml}$ of this solution was fed to Atomic Absorption Spectrophotometry (AAS) to determination of the available zinc content.

\section{Determination of $\mathrm{pH}$}

The $\mathrm{pH}$ of the ZSB culture filtrates and the uninoculated samples was determined at $0,5,10$ and 15 days after inoculation. The culture was filtered using Whatman No.1 filter paper. The $\mathrm{pH}$ was estimated using Elico $\mathrm{pH}$ meter.

\section{Zinc tolerance by ZSB isolates}

Zinc is a nutrient at low concentration but toxic at higher concentration. The solubilization of zinc might limit the growth of the bacteria at higher level. Unless the cultures tolerate a higher level of zinc its solubilization may not continue. Therefore the ability of selected isolate to tolerate solubilized zinc was determined under in vitro condition in nutrient broth containing different concentrations of soluble zinc $\left(\mathrm{ZnSO}_{4}\right)$. The nutrient broth was prepared and splitted in $10 \mathrm{ml}$ aliquots in test tubes. $\mathrm{ZnSO}_{4}$ was incorporated into the broth in such a way that the final concentration of zinc was 25, 50, 100, 200, 300, 400 and 500 $\mathrm{mg} \mathrm{kg}^{-1}$. These solutions were divided in $10 \mathrm{ml}$ quantities in test tubes, sterilized at $15 \mathrm{psi}$ for $15 \mathrm{~min}$ and inoculated with $0.1 \mathrm{ml}$ of ZSB. An uninoculated control was also maintained. The total ZSB population was assessed by plating on nutrient agar media. The growth of bacteria in the zinc containing medium indicated their tolerance to zinc. The highest concentration at which poor growth was observed was taken as tolerance level. The experiments were carried out in a completely randomized design and the data obtained were subjected to statistical analysis of variance (10).

\section{RESULTS AND DISCUSSION}

Zinc solubilizing potential varied with each isolate (Table 1). The ZSB-O-1 (Bacillus sp.) obtained from the zinc ore exhibited the highest potential in Sphalerite $(\mathrm{ZnS})$ containing medium, producing a clearing zone of $2.80 \mathrm{~cm}$ with a zone area of 14.50 $\mathrm{cm}^{2}$. Its performance in zinc carbonate and zinc oxide was 1.50 $\mathrm{cm}$ of clearing zone and zone area of $8.50 \mathrm{~cm}^{2}$ with zinc carbonate and $1.80 \mathrm{~cm}$ of clearing zone and zone area of $8.00 \mathrm{~cm}^{2}$ with zinc oxide, respectively. On the other hand, the ZSB-S-2 (Pseudomonas sp.) produced maximum clearing zone of $3.30 \mathrm{~cm}$ and zone area of $20.43 \mathrm{~cm}^{2}$ with zinc oxide and performed poorly in zinc carbonate, with a clearing zone of $2.00 \mathrm{~cm}$ and zone area of $7.00 \mathrm{~cm}^{2}$. The ZSB-S-4 (Pseudomonas sp.) showed the highest potential in zinc carbonate, with a clearing zone of $4.00 \mathrm{~cm}$ and $19.60 \mathrm{~cm}^{2}$ zone area.

The findings were confirmed in the broth assay using the same chemicals (Figs. 1, 2 and 3). The results revealed higher $\mathrm{Zn}$ solubilization on $15^{\text {th }}$ day by the isolates ZSB-O-1, ZSB-S-2 and ZSB-S-4 with $13.6 \mathrm{mg} \mathrm{kg}^{-1}$ of zinc in sphalerite, $16.4 \mathrm{mg} \mathrm{kg}^{-}$ ${ }^{1}$ in the $\mathrm{ZnO}$, and $13.4 \mathrm{mg} \mathrm{kg}^{-1} \mathrm{ZnCO}_{3}$ respectively.

All cultures showed a shift in $\mathrm{pH}$ after growth in the broth (Figs. 4, 5 and 6). After 15 days, the $\mathrm{pH}$ of the broth was acidic in all cultures. The $\mathrm{pH}$ shifted from 7-7.3 to 4.8-6.5. The ZSB-S4 culture showed the lowest $\mathrm{pH}$ value (4.8) on $15^{\text {th }}$ day after inoculation, indicating a higher acidity due to growth.

Even at $25 \mathrm{mg} \mathrm{kg}^{-1}$ concentration, there was reduction in population within 24 hours and afterwards population remained stable up to 8 days (Table 2). At zinc concentration above 100 $\mathrm{mg} \mathrm{kg}^{-1}$, a further reduction in population was observed, which was more pronounced at $200 \mathrm{mg} \mathrm{kg}^{-1}$. The results showed the inherent capacity of the isolates to tolerate various levels of zinc. At $500 \mathrm{mg} \mathrm{kg}^{-1}$ level, ZSB-S-2 was completely inhibited at the $8^{\text {th }}$ day, while ZSB-O- 1 recorded $2 \times 10^{4}$ cells $\mathrm{ml}^{-1}$ at the $8^{\text {th }}$ day after inoculation compared to $180 \times 10^{6}$ cells ml-1 observed just after inoculation. For both isolates, there were no significant differences on the $24^{\text {th }} \mathrm{h}$ of inoculation, but on $8^{\text {th }}$ day after inoculation in the ZSB-O-1, the population $\left(2 \times 10^{4}\right.$ cells $\left./ \mathrm{ml}^{-1}\right)$ recorded at $25 \mathrm{mg} \mathrm{kg}^{-1}$ concentration was found to be superior than in any other concentration of zinc. All other treatments are statistically on par. In ZSB-S-2 isolate, the population recorded in $25,50,100,200$ and $300 \mathrm{mg} \mathrm{kg}^{-1}$ of zinc were on par with each 
Table 1. Zinc solubilizing potential of zinc solubilizing bacterial (ZSB) isolates with different insoluble zinc compounds.

\begin{tabular}{|c|c|c|c|c|c|c|c|c|c|}
\hline \multirow[t]{2}{*}{ Isolates } & \multicolumn{3}{|c|}{ Zinc oxide } & \multicolumn{3}{|c|}{ Zinc carbonate } & \multicolumn{3}{|c|}{ Sphalerite } \\
\hline & $\begin{array}{c}\text { Colony } \\
\text { diameter }(\mathrm{cm})\end{array}$ & $\begin{array}{l}\text { Clearing } \\
\text { zone }(\mathrm{cm})\end{array}$ & $\begin{array}{l}\text { Area } \\
\left(\mathrm{cm}^{2}\right)\end{array}$ & $\begin{array}{c}\text { Colony } \\
\text { diameter }(\mathrm{cm})\end{array}$ & $\begin{array}{l}\text { Clearing } \\
\text { zone }(\mathrm{cm})\end{array}$ & $\begin{array}{l}\text { Area } \\
\left(\mathrm{cm}^{2}\right)\end{array}$ & $\begin{array}{c}\text { Colony } \\
\text { diameter }(\mathrm{cm})\end{array}$ & $\begin{array}{l}\text { Clearing } \\
\text { zone }(\mathrm{cm})\end{array}$ & $\begin{array}{l}\text { Area } \\
\left(\mathrm{cm}^{2}\right)\end{array}$ \\
\hline ZSB-O-1 & 1.4 & 1.8 & 8.0 & 1.8 & 1.5 & 8.5 & 1.5 & 2.8 & 14.5 \\
\hline ZSB-S-2 & 1.8 & 3.3 & 20.43 & 1.0 & 2.0 & 7.0 & 1.8 & 2.5 & 14.5 \\
\hline ZSB-S-4 & 1.2 & 2.4 & 10.18 & 1.0 & 4.0 & 19.6 & 1.0 & 1.2 & 3.8 \\
\hline
\end{tabular}

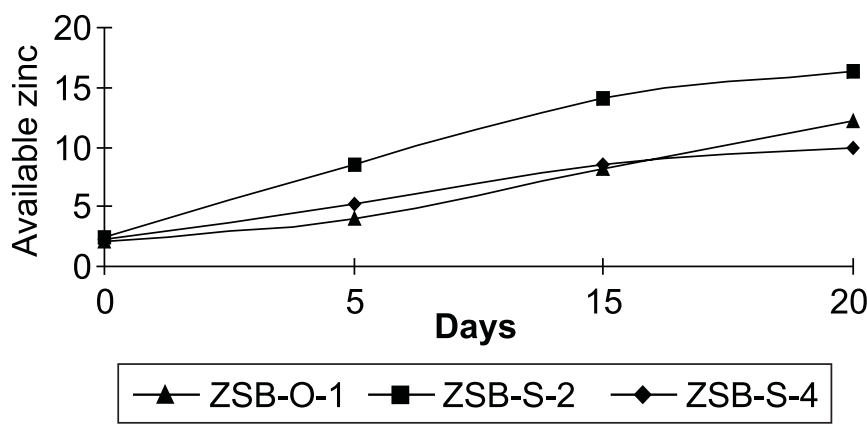

Figure 1. Available zinc $\left(\mathrm{mg} \mathrm{kg}^{-1}\right)$ in broth containing zinc oxide.

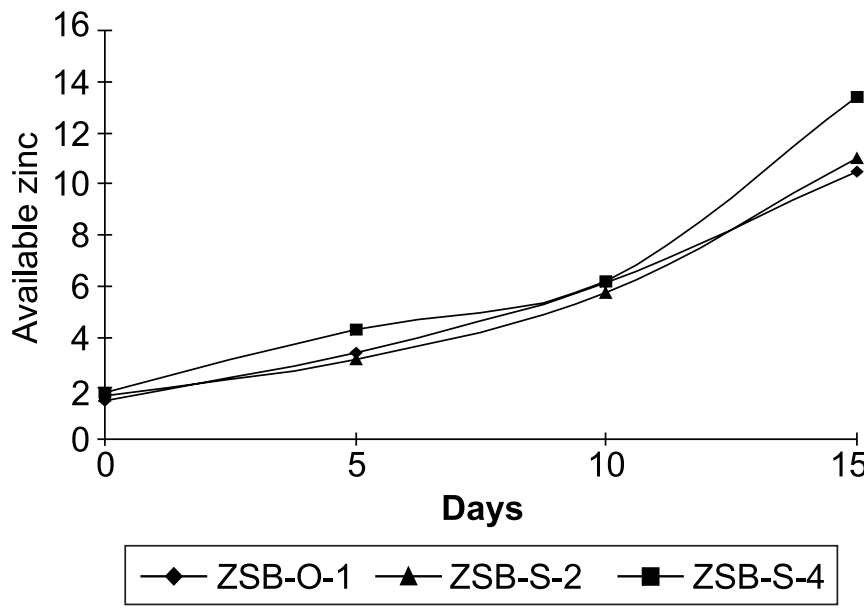

Figure 2. Available zinc $\left(\mathrm{mg} \mathrm{kg}^{-1}\right)$ in broth containing zinc carbonate.

other. But, statistical difference existed in populations at 400 and $500 \mathrm{mg} \mathrm{kg}^{-1}$ of zinc.

From the results, it is clear that available zinc levels increased with the increase in incubation period. This might be due to the presence of excess zinc even after the absorption by the microbial cells. The bioaccumulation of $\mathrm{Cu}, \mathrm{Zn} \mathrm{Cd}$ and $\mathrm{Pb}$ in the

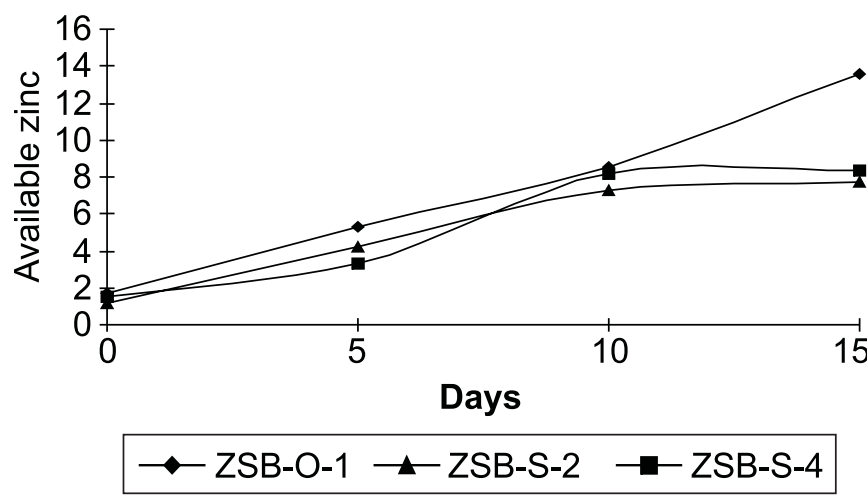

Figure 3. Available zinc (ppm) in broth containing Sphalerite.

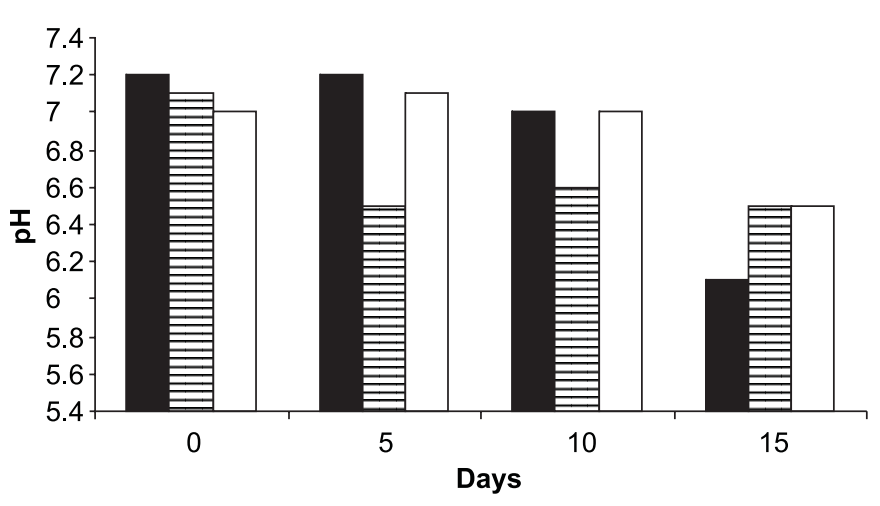

ZSB-O-1 目ZSB-S-2 $\quad$ 口ZSB-S-4

Figure 4. Changes in $\mathrm{pH}$ with zinc oxide as zinc source.

cells of Bacillus sp. Bacillus cereus, Bacillus sphaericus and Bacillus subtilis were well studied (6). After enough absorption, the excess remains in the solution. This is in agreement with the findings of Cozzi et al. (5), who stated that the complexing agents produced by microbes stabilized the inorganic ions in the solution and kept them from precipitation or in some cases, 


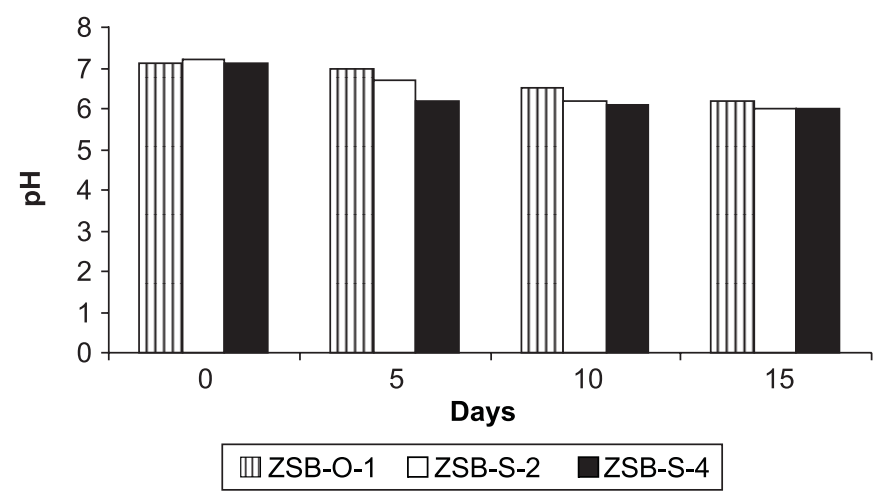

Figure 5. Changes in $\mathrm{pH}$ with zinc carbonate as zinc source.

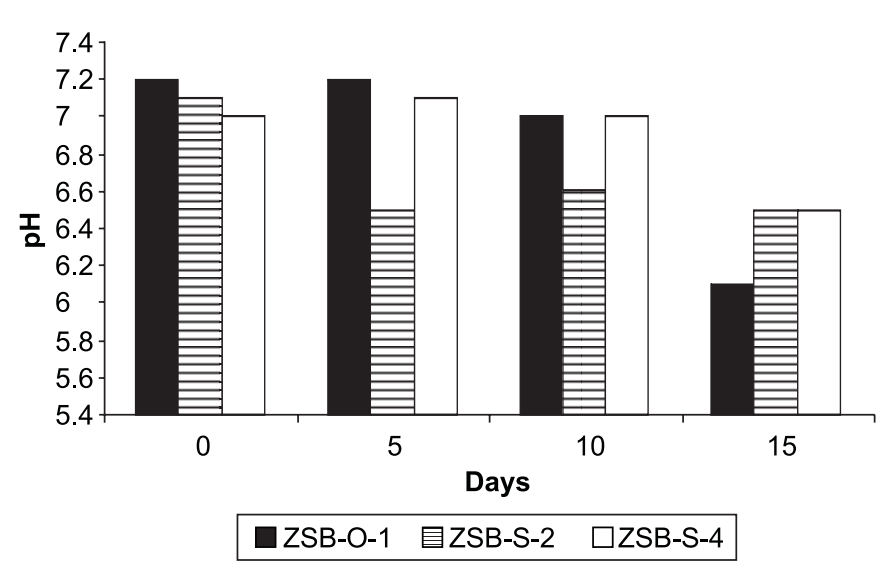

Figure 6. Changes in $\mathrm{pH}$ with Sphalerite as zinc source.

prevented from being oxidized or reduced and converted to insoluble forms.

A varied solubilization potential was found among the bacterial isolates. This might be related to differences in the location from which they were isolated. The ZSB-O-1 showed higher solubilizing ability in the $\mathrm{ZnS}$ (sphalerite) ore containing medium and this may be attributed to the fact that this strain was isolated from the same ore material, presenting a higher potential than other cultures, making their adherence with the ore particles capable of solubilizing ore. Eletron microscopy studies evidenced direct attack of microorganisms to the surface of minerals, and has shown that bacteria attach themselves to surfaces, causing deep pitting and eventually dissolution of the crystal (1). This may be the case also in the present study. Dissolution of the ore and other material may be due to production of organic acids, like gluconic acids (especially 2 keto gluconic acids). The zinc phosphate solubilization by Pseudomonas fluorescens was investigated by Simine et al. (11). They found that gluconic acid and 2 keto
Table 2. Extent of zinc tolerance of zinc solubilizing bacterial (ZSB) isolates.

\begin{tabular}{|c|c|c|c|c|c|c|c|}
\hline \multirow{3}{*}{$\begin{array}{c}\text { Strain } \\
\mathrm{N}^{\mathrm{o}}\end{array}$} & \multirow{3}{*}{$\begin{array}{c}\text { Zinc } \\
\text { concentration } \\
\left(\mathrm{mg} \mathrm{kg}^{-1}\right)\end{array}$} & \multicolumn{6}{|c|}{ Population $\left(1 \mathrm{X} 10^{6} \mathrm{ml}^{-1}\right)$} \\
\hline & & \multicolumn{3}{|c|}{ ZSB-O-1 } & \multicolumn{3}{|c|}{ ZSB-S-2 } \\
\hline & & $\mathrm{Oh}$ & $24 \mathrm{~h}$ & 8DAI & $\mathrm{Oh}$ & $24 \mathrm{~h}$ & 8DAI \\
\hline 1. & 0 & 180 & 250 & 250 & 200 & 270 & 200 \\
\hline 2. & 25 & 180 & 28 & 25 & 200 & 16 & 20 \\
\hline 3. & 50 & 180 & 21 & 21 & 200 & 16 & 20 \\
\hline 4. & 100 & 180 & 20 & 20 & 200 & 18 & 18 \\
\hline 5. & 200 & 180 & $16^{*}$ & $14^{*}$ & 200 & $14^{*}$ & $12^{*}$ \\
\hline 6. & 300 & 180 & $11 *$ & $12^{*}$ & 200 & $14^{*}$ & $13^{*}$ \\
\hline 7. & 400 & 180 & $6^{*}$ & $8 *$ & 200 & $8^{*}$ & $7 *$ \\
\hline \multirow[t]{3}{*}{8.} & 500 & 180 & $4^{*}$ & $2 *$ & 200 & $5^{*}$ & $*$ \\
\hline & SEd & & 3.22 & 1.50 & & 1.61 & 1.21 \\
\hline & CD & & 7.14 & 3.22 & & 3.47 & 2.60 \\
\hline
\end{tabular}

* Population $10^{4}$ cells $\mathrm{ml}^{-1}$; $\mathrm{h}$ - hours; DAI - Days After Inoculation; SEd - Standard Error Deviation; CD - Critical Difference.

gluconic acids produced in the culture broth helped in the solubilization of the zinc salts. Since all the cultures showed a shift in $\mathrm{pH}$ towards acidic range, it gives a clue that organic acid might be involved.

The zinc tolerance potential also varied with the organisms. The ZSB-O-1 cultures is a Bacillus sp., and had shown a cell count of $2 \times 10^{4} \mathrm{ml}^{-1}$ on the $8^{\text {th }}$ day after inoculation in a $500 \mathrm{mg}$ $\mathrm{kg}^{-1}$ concentration of zinc. This might be due to production of spore cells by the Bacillus sp. which when transferred to a rich media like nutrient agar were able to retain their growth, whereas the ZSB-S-2 was completely inhibited at $500 \mathrm{mg} \mathrm{kg}^{-1}$ concentration after 8 days of inoculation since it is a Pseudomonas sp. It may not be able to survive the adverse condition of higher level of $\mathrm{Zn}$ and so a complete inhibition was observed.

Thus, the obtention of an elite culture or a consortium of strains capable of utilizing different unavailable insoluble forms of zinc and tolerant to higher zinc levels may be useful to make zinc available in the soil system. Soils are naturally rich in total zinc but lack available zinc. Application of soluble zinc sulphate to alleviate zinc deficiency in certain soils is a costly practice. Selection and inoculation of zinc solubilizing bacteria either alone in soils inherently rich in native zinc or along with cheaper insoluble zinc compounds, like $\mathrm{ZnO}$ or $\mathrm{ZnCO}_{3}$, will lead to lot of saving in crop husbandry, besides curtailing the expenditure on agro input. Since zinc in soil system is constantly changing forms and being converted to unavailable forms, this particular study gains momentum for zinc nutrition using microbes. 


\section{RESUMO}

\section{Avaliação In vitro do potencial de solubilização de diferentes bactérias solubilizadoras de zinco (ZSB)}

A capacidade de Bacillus sp. e Pseudomonas sp. solubilizar zinco foi avaliada usando óxido de zinco, sulfeto de zinco e carbonato de zinco, em ensaios em placas e em caldo. A cultura ZSB-O-1 (Bacillus sp.) apresentou maior dissolução no sulfeto de zinco, com 2,80 cm de zona de dissolução e $14,50 \mathrm{~cm}^{2}$ de área no ensaio em placa e $13,60 \mathrm{mg} \mathrm{kg}^{-1}$ de zinco no ensaio em caldo, no $15^{\circ}$ dia de incubação. A cultura ZSB-S-2 (Pseudomonas sp.) apresentou maior capacidade de dissolução no óxido de zinco, com 3,30 cm de zona de dissolução e $20,43 \mathrm{~cm}^{2}$ de área no ensaio em placa e $16,40 \mathrm{mg} \mathrm{kg}^{-1}$ de zinco no ensaio em caldo no mesmo período de inoculação. A cultura ZSB-S-4 (Pseudomonas sp.) apresentou maior potencial de solubilização em carbonato de zinco, com 6,20 cm de zona de dissolução e $13,40 \mathrm{~cm}^{2}$ de área no ensaio em placa e $13,40 \mathrm{mg} \mathrm{kg}^{-1}$ de zinco no ensaio em caldo. Assim, o potencial de solubilização variou de acordo com a cultura. A solubilização pode ser devida à produção de ácido, uma vez que o $\mathrm{pH}$ do caldo abaixou de 7,0-7,3 para 4,8-6,5 após 15 dias de incubação. O limite de tolerância ao zinco para as duas culturas (ZSB-O-1 and ZSB-S-2) foi mensurada, verificandose ser $100 \mathrm{mg} \mathrm{kg}^{-1}$ no ensaio in vitro em caldo.

Palavras-chave: Bacillus sp., Pseudomonas sp., bactérias solubilizadoras de zinco

\section{REFERENCES}

1. Bennett, J.C.; Tributsch, H. Bacterial leaching patterns on pyrite crystal surfaces. J. Bacteriol., 134: 310-317, 1978.

2. Bullen, P.; Kemila, A.P.F. Influence of $\mathrm{pH}$ on the toxic effect of zinc, cadmium and pentachlorophenol on pure cultures of soil microorganisms. Entl. Toxi. Chemi., 16: 146-153, 1997.

3. Bunt, J.S.; Rovira, A.D. Microbiological studies of some subantartic soils. J. Soil Sci., 6: 119-128, 1955.

4. Chernavina, P. Importance of trace elements in pigment production of microbes. Molekulasnaya Biologiya., 6: 340-355, 1970.

5. Cozzi, D.; Desidevi, P.G.; Lepri, L. The mechanism of ion exchange with alginic acid. J. Chromatogr., 40: 130-135, 1969.

6. Da Costa, A.C.A.; Duta, F.P. Bioaccumulation of Copper, Zinc, Cadmium and Lead by Bacillus sp., Bacillus cereus, Bacillus sphaericus and Bacillus subtilis. Braz. J. Microbiol., 32: 1-5, 2001.

7. Hughes, M.N.; Poole, R.K. Metals and microorganisms. Chapman and Hall, London. pp.412, 1989.

8. Hutchins, S.R.; Davidson, M.S.; Brierey, J.A.; Brierley, C.L. Microorganisms in reclamation of metals. Ann. Rev. Microbiol., 40 311-336, 1986.

9. Parisi, B.; Vallee, B.L. Metal enzyme complexes activated by zinc. J. Biol. Chem., 179: 803-807, 1969.

10. Panse, V.G.; Sukhatme, P.V. Statistical methods for agricultural workers, ICAR Publn., New Delhi. India. 1967

11. Simine, C.D.D.; Sayer, J.A.; Gadd, G.M. Solubilization of zinc phosphate by a strain of Pseudomonas fluorescens isolated form a forest soil. Biol. Fertil. Soils., 28: 87-94, 1998.

12. Vinogradov, A.P. Trace elements and the goals of science. Agrokhimiya, 8: 20-31, 1965. 